\title{
Teacher-Equalization-Policy Implementations in Maluku Province
}

\author{
Patris Rahabav ${ }^{1, *}$, Insun Sangaji ${ }^{2}$, Paula Tahapary $^{2}$, and Ervana Nelawaty Aponno ${ }^{2}$ \\ ${ }^{1}$ Pattimura University, Indonesia \\ ${ }^{2}$ Education and Culture Office of Maluku Province, Indonesia \\ *Corresponding author. Email: patrisrahabav1960@gmail.com
}

\begin{abstract}
Analysis of the ratio of teachers to students, there has been an excess of teachers in all districts. Meanwhile, the analysis of the ratio of students to teachers based on the subject areas they are teaching is still a mismatch. The problem of teacher shortages is due to lower regulations as the elaboration of the 5 Ministerial Joint Decree on teacher governance and distribution. The level of eligibility of school principals and teachers in Maluku Province is in the less appropriate category (65\%). To overcome this problem, a regulation at the regional level is needed as an elaboration of the Ministerial Decree that regulates teacher governance and distribution; Addition of teacher quota through transparent, accountable and measurable selection on a priority scale for placement in disadvantaged areas; Teacher replacement and redistribution according to competence to prevent disparities; Collaboration partnerships with educational institutions for education personnel so that Field Experience Practical students are integrated with the Real Work Lecture program so as to help schools with teacher shortages; Mobile Teacher which enables teacher mobility from superior schools to schools with underperforming regularly; Recruitment of superior seeds for high school graduates with official bond scholarships for study at educational institutions and ready to be employed in schools that lack teachers after graduating and recruitment of alternative teachers on a priority scale for local boys.
\end{abstract}

Keywords: Implementation, Policy, Equity of Teachers.

\section{INTRODUCTION}

Teacher is one of the most important elements that determines the quality of learning in schools. One of the problems of teachers that is very prominent today is uneven distribution and arrangement. In Washington, United States it was found that the unequal distribution of teachers is still an unsolved problem, Goldhaber, Lavery, and Theeobald [1]. The unequal distribution of teachers is also a major problem found in rural China, Paine [2] Han [3]. In addition to distribution, teacher placement still raises various problems. Teacher placement is one of the factors that determine the quality of education. Therefore, identification of problems related to teacher placement can help schools make appropriate interventions to improve teacher performance, Karma and Lhaden [4].

Legally-formally, the policy for equal distribution of teachers in Indonesia has gained legitimacy with the Joint Decreeof 5 Ministers, namely the Minister of National Education, the State Minister for Administrative Reform and Bureaucratic Reform, the Minister of Home Affairs, the Minister of Finance, and the Minister of Religion 05/x/pb/2011, SPB/03/m.panrb/10/2011, Number 48 of 2011, Number 158/pmk.01/2011 and Number 11 of 2011, concerning Structuring and Equity of Civil Servant Teachers.

The Joint Decreeof 5 Ministers is a public policy. According to experts, policy terminology is often interchanged with other terms such as goals, programs, decrees, laws, provisions, standards, proposals, and grand designs, Anggara [5]. Etymologically, the term policy is a translation from English, public policy. The word policy means a policy, while the public is a group of people who have the same interests and interests on an issue or problem. The policy is the formulation of rules, norms, and recipes that are intended to govern government decisions and actions, Baldwin [6].

Public policy is a broad guide to existing and future decisions, selected from several alternatives; an actual decision or a series of decisions designed to carry out the selected action; projected in the program to achieve the goals and objectives to be achieved, Daneke and Steiss as cited in Rahabav [7]. Public policy is a broad framework of ideas and values and actions decided by the government to solve various public problems, Brooks as cited in Rahabav [8].

Based on the previous definitions, public policy is formulated as a decision that is deliberately made by the government to respond and realize public needs consistently. Public policy analysis is a form of analysis that presents information in such a way that it provides a basis for making decisions, Dunn [9].

The Joint Decree of 5 Ministers must be implemented by relevant cross-sectoral agencies in the arrangement and distribution of teachers. The authority of the Provincial and Regency/City Governments is 
contained in Article 4, Joint Decree of 5 Minister: Paragraph (1) The governor is responsible and obliged to organize and distribute civil servant teachers between educational units, between levels, and between types of education in education units organized by the provincial government that has excess or shortage of civil servant teachers. (2) The regent/mayor is responsible for and obliged to organize and distribute civil servants (Pegawai Negeri Sipil (PNS)) teachers between education units, between levels, and between types of education in education units organized by district/city governments with excess and shortage of PNS teachers. (3) The governor coordinates and facilitates the transfer of civil servant teachers for the arrangement and distribution of civil servant teachers between educational units, between levels, and between types of education in their working areas under their respective authorities. (4) The Regent/Mayor coordinates and facilitates the transfer of civil servant teachers for the arrangement and distribution of civil servant teachers between education units, between levels, and between types of education in their working area under their respective authority.

All parties hope that this policy will have a direct impact on improving the quality of education in general and in particular the improvement of the quality of student learning. The equality and distribution of teachers in Indonesia still face various obstacles. In Indonesia in general, Mismatches still occur; both in terms of the imbalance of the ratio of students to teachers and mismatch in terms of the imbalance of teachers with the competence of the subject areas being handled.

The results of the study show that overall there is still a shortage of teachers in the Basic Education Unit of 146,987 , with details of primary schools having excess teachers of 90,618, special schools lacking teachers of 3,596, junior high schools having excess teachers of 34,901 , senior high schools having teacher shortages of 160,661 and vocational high schools. teacher shortage of 108,249 . Based on the ratio of students per teacher according to need, it is also clear that the primary school is 15.18 greater than the existing 14.42 , so there is an excess of teachers, as well as junior high schools of 15.53, which is greater than 14.73., resulting in excess teachers. On the other hand, the ratio of students per teacher according to needs at Special Schools, Senior High Schools, and Vocational High Schools, respectively, is $3.75,9.45$, and 11.36 , which is smaller than that of 4.25 respectively. 14.57 , and 15.86, resulting in a shortage of teachers, Kemdikbud [10].

The results of a study conducted at the Office of Youth and Sports Education, Central Maluku Regency) show that in the district. Central Maluku Civil servant teachers are not evenly distributed in Public Elementary Schools, State Junior High Schools, and Public Senior High Schools in Central Maluku because there is no regulation / legal umbrella issued by the Regional Government or authorized officials, in this case, the Regent of Central Maluku regarding equity. Civil servant teacher, Agnesty [11]. The policy of equalization and distribution of teachers in the South Buru Regency has not been evenly distributed, Loilatu [12]. Teachers are not evenly distributed in State Senior High Schools and Vocational High Schools in Southwest Maluku Regency. The unequal distribution of teachers has resulted in a gap in the number of teachers between schools. On the one hand, there is an excess number of teachers for several subjects in several Districts, on the other hand, there is a shortage of teachers in other Districts, Evita [13].

The unequal distribution of teachers in Indonesia is not a simple problem. If analyzed, there are at least seven factors that influence the policy of structuring and equalizing teachers, namely (1) inconsistency of the central government in implementing the Joint Decree of 5 Minister. The Joint Decree of 5 Minister products, were successful in formulation but failed in implementation; 2) The Joint Decree 5 Ministerial Regulation has not been translated into lower regulations at the regional level in the form of Regional Regulations or Governor Regulations as the basis for implementation; 3) The analysis of teacher needs has not been used as a basis for local governments in structuring and distributing teachers; 4) weak teacher management information system; 5) The low commitment of teachers to work in rural areas, especially in the frontier, outermost and disadvantaged areas (3T) which is triggered by the difficulty of limited access to information, the strong desire of teachers to improve qualifications and competencies that are generally only available in cities and the low welfare of teachers; 6) Weak supervision and law enforcement of policy makers for teachers who are not disciplined in carrying out their duties and 7) Intervention of local political elites in the recruitment, distribution and placement of teachers as remuneration for political support obtained during the Election of Regional Heads and Regional Representatives Council.

The unequal distribution of teachers is further exacerbated by the low results of the Teacher Competency Test. Indonesia's low ranking in the fields of reading, mathematics, and science also indirectly indicates the weakness of teacher competencies. The national average, the 2018 Teacher Competency Test result in pedagogic and professional fields is 53.05. For pedagogical competence alone, the national average is only 48.94, which is below the minimum competency standard, which is 55, Kemdikbud [14]. Specifically, the UKG results for Maluku Province were still below the national passing grade, which only reached 46.57; puts Maluku Province in the $33^{\text {rd }}$ position, only one point away from North Maluku Province which occupies a key position. 
Teacher competence, as described above, correlates with the quality of education in Indonesia. The results of the Program for International Student Assessment (PISA) in 2018 reported that the reading ability of Indonesian students was in the poor category with countries such as Saudi Arabia, Morocco, Kosovo, the Dominican Republic, or Kazakhstan, and the Philippines. The average reading ability of OECD countries stands at 371 . The first place is achieved by China (score 555); followed by Singapore (549) and Macau (525). Math and science scores below average. The average PISA score of OECD member countries for mathematics and science was 489. Indonesia's 2018 score of mathematics was around 379 and science was 396 while China was 591 and Singapore was 569, Kompas.com [15].

At the national level, the quality of education in Maluku Province is still concerning. Until 2019, Maluku Province still ranks 33 out of 34 Provinces [Head of Education and Culture Office of Maluku Province, 2020]. In that context, the implementation of the policy for equal distribution of teachers in high schools and vocational schools through this study is very strategic. Implementation is a very important route to find out whether a policy, strategy or program succeeds or fails. In the realm of implementation of science, the definition of implementation focuses on how a person can produce change through certain interventions. Implementation is "Suatu proses kegiatan yang didesain secara sistimatis untuk mewujudkan program atau kegiatan untuk mencapai tujuan yang telah ditetapkan" (an activity process designed systematically to realize a program or activity to achieve predetermined goals" Fixsen [16]

The meta-analysis study found some significant resultshat monitoring of policy implementation produces a three times greater effect when compared to unmonitored implementation. Another study, which involved more than 200 school-based aggression prevention programs, found that "implementation" was the second most important predictor of all the predictors studied that had a direct effect on performance. Another study found that by monitoring the implementation of the intervention, performance " will be 12 times more effective" Durlak and DuPre [17]. Policy implementation can simply be interpreted as a process of translating regulations into action. In practice, policy implementation is a process that is so complex that it is often politically charged because it takes the form of interventions with various interests [18].

Measuring the success of policy implementation can be seen from the process by questioning whether program implementation is under what has been determined, namely looking at the action program of individual projects and second, whether the program objectives are achieved". It should be noted that policy implementation is a very important stage in the overall policy structure because it is through this procedure that a public problem can be resolved or not.

A meta-analysis study found strong empirical support that the implementation of policy affects the results obtained to prevent programs from failure. By implementing policies, it will be known to what extent the level of effectiveness of a policy so that corrective or corrective action can be taken.

The objectives of this study are: 1) analyzing the distribution and distribution policies for high school and vocational high school teachers in Maluku province; 2) Analysing the feasibility level of school principals and teachers of Senior High School and Vocational High School in Maluku Province.

\section{RESEARCH METHODS}

\subsection{Research Design}

The type of research method chosen is descriptive, which describes the amount. Qualifications, competencies and distribution of teachers at SMA and SMK in Maluku Province are processing and analysing to draw conclusions.

\subsection{Research Subjects}

The subject of this study was 395 principals of high schools and vocational high schools in Maluku Province, with details: 282 of high school principals and 113 of vocational school principals. The sample technique used is the census technique.

\subsection{Data Collection Methods}

\subsubsection{Documentation Study}

The documentation study was carried out to collect data on the number of school principals, teachers, students that is available in schools and the Maluku Province Education and Culture Office and the Education and Culture Office Branches in 11 Districts / Cities in Maluku Province both in the form of data and information available in school statistics, Main data of education that is processed, aspects of legality or legislation, government regulations, regulations of the Minister of Education and Culture, guidelines and various other scientific research works.

\subsubsection{Questionnaire}

The questionnaire was used to collect 2 types of data, namely basic data related to elementary school statistics (teachers and principals). Based on statistical data, it is obtained the needs of school principals and teachers at vocational high schools and vocational schools in Maluku Province. Furthermore, an analysis of the strengths and weaknesses of school principals and 
teachers is conducted using certain standards, Kintamani [19].

The second data, namely the eligibility of human resources (principals and teachers) includes 6 indicators: qualifications, the suitability of diplomas with the subject areas being handled, competence (professional certificates), rank/class, the legality of teachers and school principalsand experience, principal and teacher. By using the 6 indicators of the feasibility of human resources, it can be calculated the feasibility level of human resources for 2 units of education (high school and vocational high school) in Maluku Province.

\subsection{Data Analysis Methods}

The data analysis technique used in this research is descriptive. Data analysis consisted of two parts, namely based on school statistical data and based on the feasibility of HR indicators. Based on statistical data, it is obtained the needs of school principals and teachers in the field of study in high school and vocational high school education units. Furthermore, an analysis of the strengths and weaknesses of school principals and teachers is carried out using certain standards.

\subsubsection{Analysis of the Need for Teachers and Principals of High Schools}

The needs of subject teacher are calculated from the number of classes per level multiplied by the hours of study for a particular subject according to the curriculum (high school curriculum) divided by 24 hours, namely the teacher's compulsory teaching hours, the formula is:
TGMP at $=$ additional subject a teacher in the year

$\mathrm{t}$ BGMP $\mathrm{a}=$ the need for subject a teacher in the year

t GMP at $=$ subject a teacher in the year

t. a = types of subjects; for example, Civics, Religious Education, Indonesian Language, and so forth.

Note: If there are more subject teachers than needed, there will be an excess of subject teachers. On the other hand, the existing subject teachers are smaller than needed, so there is a shortage of subject teachers.

\subsubsection{Analysis of the Needs of Teachers and Principals of Vocational Schools}

Subject teacher needs are calculated from the number of classes multiplied by the hours of study for a particular subject according to the vocational high school curriculum divided by 24 hours, namely the teacher's compulsory teaching hours, the formula is:

$$
\begin{aligned}
& \text { Index: } \\
& \begin{array}{ll}
\text { MP } & =\text { subject } \\
\text { a } & =\text { subject a }(10 \text { general subjects and } \\
\text { vocational high school expertise program } & \\
\mathrm{t} & =\text { year }
\end{array} \\
& \text { BGMP at }=\text { the need for subject a teacher in year } \mathrm{t}
\end{aligned}
$$

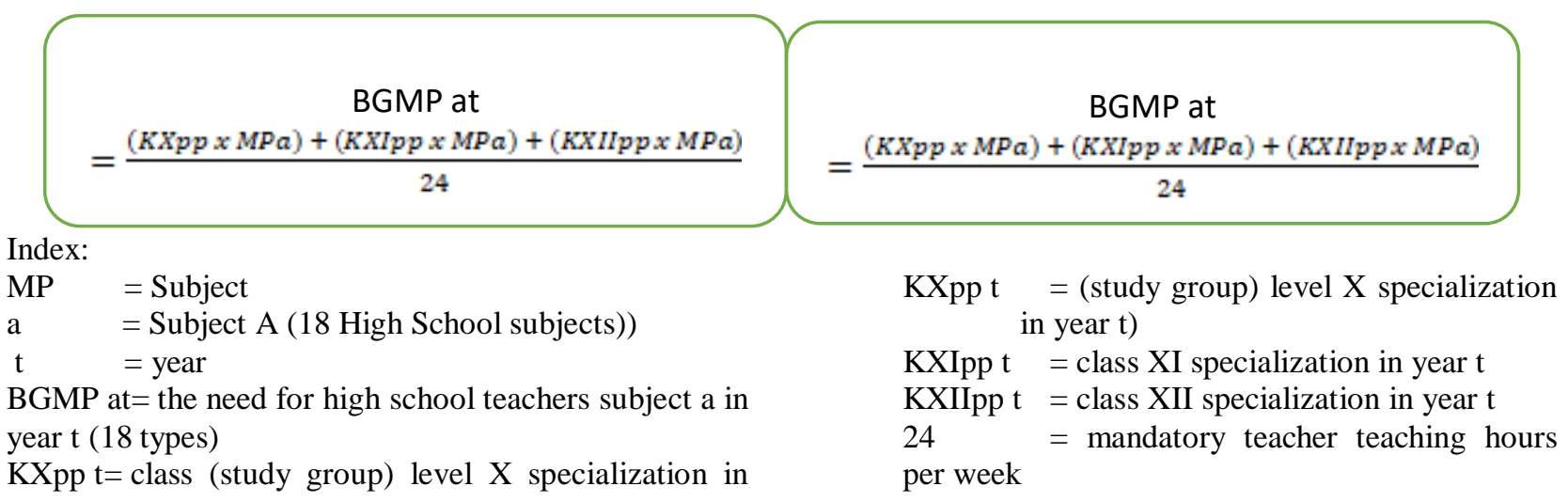
year $\mathrm{t}$

KXIpp $\mathrm{t}=$ class XI specialization in year $\mathrm{t}$

KXIIpp $\mathrm{t}=$ class XII specialization in year $\mathrm{t}$

$24=$ mandatory teacher teaching hours per week

Thus, additional subject teachers required are:

TGMP at = BGMP at - GMP at

Index :
Thus, additional general subject teachers are required:

TGMP at $=$ BGMP at - GMP at

Index:

TGMP at = additional subject a teacher

BGMP at

in year $\mathrm{t}$

$=$ the need for subject

teachers a in year $\mathrm{t}$

GMP at 
at

= types of subjects; for
example,
$\begin{aligned} & \text { Education, Civics, } \\ & \text { Indonesian }\end{aligned}$
Mathematics, Language,
English, Cultural
Arts, Physical Education,
Local Content, Expertise
Programs, and so forth

Note: If the number of existing subject teachers is greater than the need, there will be an excess of subject teachers. On the other hand, the existing subject teachers are smaller than needed, so there is a shortage of subject teachers.

The feasibility analysis for teachers and school principals consists of 6 indicators, namely: percentage of school principal and teacher qualifications (\% KPSG), percentage of diploma suitability with the subject area being managed (\% KIBD), percentage of principal and teacher competence (\% KPSG), percentage of rank/groups of school principals and teachers ( $\% \mathrm{KGKSG})$, percentage of the legality of principals and teachers (\% LKSG), percentage of experiences of principals and teachers (\% PKSG).

To get the percentage of each indicator, the following formula is used

Total Score Achievement Indicators $\%$ Indicator $=$ $\mathrm{x} 100$

Teachers

Total Principals and

To get the ideal score for the principal and teacher, the Benchmark Reference Assessment (Penilaian Acuan Patokan $(P A P))$ approach is used with the following criteria:

$$
\begin{array}{ll}
90-100 \% & =\text { very feasible } \\
80-89 \% & =\text { feasible } \\
70-79 \% & =\text { pretty feasible } \\
60-69 \% & =\text { less feasible } \\
<60 \% & =\text { infeasible }
\end{array}
$$

\section{RESULTS AND DISCUSSIONS}

\subsection{Research Findings}

\begin{tabular}{|c|c|c|c|c|}
\hline No. & Variable & $\begin{array}{l}\text { Senior High } \\
\text { School }\end{array}$ & $\begin{array}{c}\text { Vocational High } \\
\text { School }\end{array}$ & Total \\
\hline 1 & School & 282 & 113 & 395 \\
\hline 2 & Class & 2,701 & 1,084 & 3,785 \\
\hline 3 & Students & 67,038 & 22,489 & 89,527 \\
\hline \multirow[t]{3}{*}{4} & Needs & & & \\
\hline & a. Head of School & 282 & 113 & 395 \\
\hline & b. Teacher & 5,912 & 2,479 & 8,381 \\
\hline \multirow[t]{3}{*}{5} & Which exists & 3477 & 1327 & 4804 \\
\hline & a. Head of School & 282 & 113 & \\
\hline & b. Teacher & 3,477 & 1,327 & 4804 \\
\hline \multirow[t]{3}{*}{6} & Weakness / Strength & & & \\
\hline & a. Head of School & 0 & 0 & 0 \\
\hline & b. Teacher & $-2,435$ & $-1,152$ & $-3,587$ \\
\hline \multirow[t]{4}{*}{7} & $\mathrm{~S} / \mathrm{G}$ ratio & & & \\
\hline & a. Needs & 11.33 & 9.07 & 10.66 \\
\hline & b. Existing & 19.28 & 16.94 & 18.63 \\
\hline & The meaning & Exceeded & Exceeded & Exceeded \\
\hline
\end{tabular}

\subsubsection{Analysis of the needs and weaknesses/strengths of} principals and teachers

Table 1. Schools, Classes, and Students, Needs and Weaknesses / Strengths of School Principals and Teachers and the Ratio of Students per Teacher for Civil Servants in Maluku Province According to the Education Level in 2020

Based on Table 1, the number of Senior High Schools and Vocational Schools in Maluku Province in 2020, there are 395 institutions with details of 282 High Schools and 113 Vocational Schools. The number of students currently is 89,527 people; with details of 67,038 High Schools and 22,489 Vocational Schools. The number of classes/study groups currently available is 3,785 with details of 2,701 High Schools and 1,084 Vocational Schools. The number of teachers currently needed is 8,391 , but the number of teachers currently available is 4,804 .
Based on the results of the analysis of the strengths and weaknesses of teachers, Maluku Province still has a shortage of civil servant teachers in both High and Vocational Schools as many as $-3,587$ people; with details: HIGH SCHOOL teachers as many as $-2,435$ people and Vocational School as many as $-1,152$ people. The results of the calculation of the ratio of students and teachers based on education units; for high school, it is obtained that the number of needs is greater than the existing ones (19.28> 11.33); In Vocational Middle Schools, the same thing happened, namely that there 
were more teachers than available (16.94> 9.07). The results of the above calculations provide information that when viewed from the ratio of students to teachers based on education units, there is an excess of teachers in Maluku. Meanwhile, if it is seen from the ratio of students to teachers based on the subject areas they are teaching, there are still disparities (mismatch).
Details of the shortage of civil servantTeachers in each District and City in Maluku Province: 253 Buru District; South Buru 285; Central Maluku as many as 1035; Southeast Maluku as many as 202; Southwest Maluku as much as 352; District of Tanimbar Islands, as many as 314; District of Aru Islands, 152; Regency. West Seram, 442; East Seram District, 250; Ambon City as many as 179 and Tual City as many as 223 . The results can be seen in Figure 1.

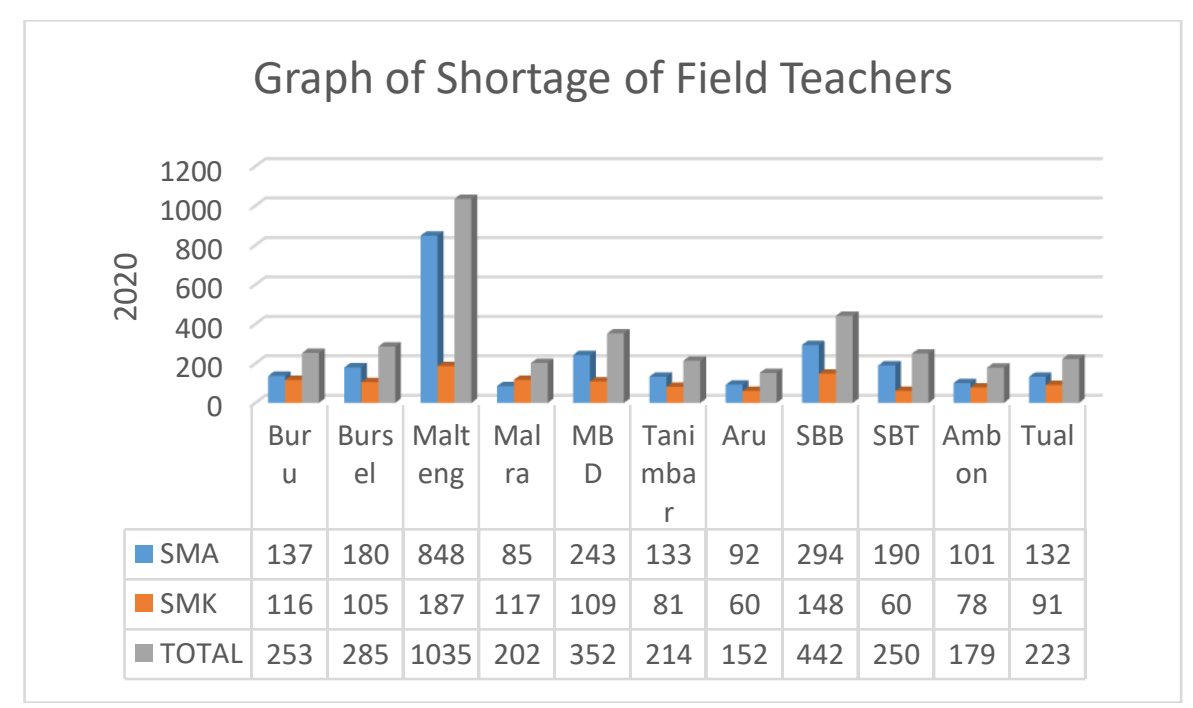

Figure 1. The Lack of Subject Teachers in Maluku Districts

Table 2. Number of Shortage of high school teachers by Regency in Maluku

\begin{tabular}{|c|c|c|c|c|c|c|c|c|c|c|c|c|}
\hline \multirow[b]{2}{*}{ No } & \multirow[b]{2}{*}{ MAPEL SMA } & \multicolumn{11}{|c|}{ KAB.KOTA } \\
\hline & & BURU & BURSEL & M. TENGAH & MALRA & MBD & $\begin{array}{c}\text { KEP. } \\
\text { TANIMBAR }\end{array}$ & $\begin{array}{l}\text { KEP. } \\
\text { ARU }\end{array}$ & SBB & SBT & AMBON & TUAL \\
\hline 1 & PEN.AGAMA ISLAM & 0 & -6 & -43 & -1 & -21 & -13 & -2 & -11 & -11 & -6 & -15 \\
\hline 2 & PEND.AGAMA KRISTEN & -9 & -1 & -23 & -5 & -10 & -6 & -1 & -3 & -1 & -1 & -10 \\
\hline 3 & PEN. AGAMA KATOLIK & -5 & 0 & -18 & 0 & -21 & -8 & -6 & -6 & -1 & -2 & -3 \\
\hline 4 & PPKN & -3 & -10 & -32 & -3 & -13 & -4 & -4 & -3 & -5 & -3 & -5 \\
\hline 5 & BHS. INDONESIA & -9 & -13 & -71 & -16 & -11 & -5 & -4 & -20 & -4 & -2 & -13 \\
\hline 6 & MATEMATIKA & -9 & -13 & -61 & -12 & -10 & -5 & -2 & -36 & -2 & -4 & -6 \\
\hline 7 & SEJARAH & -10 & -13 & -58 & 4 & -13 & -5 & -3 & -21 & -10 & -4 & -11 \\
\hline 8 & BHS. INGGRIS & -5 & -10 & -41 & 4 & -12 & -6 & -5 & -13 & 0 & -5 & 13 \\
\hline 9 & SENI BUDAYA & -14 & -14 & -85 & -11 & -21 & -13 & -10 & -23 & -21 & -22 & -10 \\
\hline 10 & PENJASKES & -15 & -12 & -79 & -4 & -15 & -4 & -5 & -26 & -16 & -5 & -16 \\
\hline 11 & TIK & -7 & -13 & 0 & 0 & -21 & -20 & -11 & -19 & -22 & -5 & -9 \\
\hline 12 & BIOLOGI & -5 & -9 & -14 & -13 & -12 & -2 & -1 & -22 & -5 & -2 & -13 \\
\hline 13 & FISIKA & -1 & -10 & -41 & -5 & -3 & -3 & -5 & -9 & -6 & -2 & -4 \\
\hline 14 & KIMIA & -1 & -9 & -43 & -4 & -5 & -7 & -5 & -1 & -5 & -4 & -1 \\
\hline 15 & GEOGRAFI & -6 & -9 & -37 & -1 & -13 & -7 & -6 & -8 & -15 & -4 & -6 \\
\hline 16 & SOSIOLOGI & -6 & -12 & -47 & -7 & -8 & -6 & -3 & -19 & -15 & -4 & -5 \\
\hline 17 & EKONOMI & -2 & -9 & -22 & -9 & -5 & -4 & -3 & -8 & -9 & -3 & -2 \\
\hline 18 & BHS. ASING (JERMAN) & -6 & -2 & -33 & -2 & -14 & -7 & -6 & -6 & -20 & -11 & -1 \\
\hline \multirow[t]{3}{*}{19} & $\mathrm{BP} / \mathrm{BK}$ & -24 & -15 & -100 & 0 & -15 & -8 & -10 & -40 & -22 & -12 & -15 \\
\hline & JUMLAH & -137 & -180 & -848 & -85 & -243 & -133 & -92 & \begin{tabular}{|l|l|}
-294 \\
\end{tabular} & \begin{tabular}{|l|l|}
-190 \\
\end{tabular} & -101 & -132 \\
\hline & GRAND TOTAL & \multicolumn{11}{|c|}{-2435} \\
\hline
\end{tabular}

The shortcomings in the subject teacher per education unit can be seen in Table 2 and Table 3 . The number of teacher shortages in senior secondary schools in Maluku varies greatly between districts. Based on the data in Table 4.3a, the number of shortages of high school teachers in Maluku is -2435 teachers, with details: Buru District, -137; Bursel Regency as much as -180; Central Maluku as much as -848; Southeast Maluku as much as -85; MBD of -243; Tanimbar Islands as much as -133; Aru Islands as much as -92 ; SBB as much as -294; SBT as much as -190; Ambon City is 101 and Tual City is 132 . 
Table 3. Number of Shortage of Vocational Middle School Teachers by District in Maluku

\begin{tabular}{|c|c|c|c|c|c|c|c|c|c|c|c|c|}
\hline \multirow[b]{2}{*}{ No } & \multirow[b]{2}{*}{ MAPEL SMK } & \multicolumn{11}{|c|}{ KAB.KOTA } \\
\hline & & BURU & BURSEL & M. TENGAH & MALRA & MBD & $\begin{array}{c}\text { KEP. } \\
\text { TANIMBAR }\end{array}$ & $\begin{array}{l}\text { KEP. } \\
\text { ARU }\end{array}$ & SBB & SBT & AMBON & TUAL \\
\hline 1 & PEN_AGAMA ISLAM & -8 & -5 & -3 & -5 & 0 & 0 & 0 & -3 & -1 & -6 & -3 \\
\hline 2 & PEND.AGAMA KRISTEN & 0 & 0 & -7 & -5 & -5 & -4 & -3 & -3 & 0 & -1 & 3 \\
\hline 3 & PEN. AGAMA KATOLIK & 0 & 0 & -1 & -6 & 0 & -3 & 0 & 0 & 0 & -8 & -3 \\
\hline 4 & PPKN & -8 & -4 & -8 & -5 & -7 & -2 & -4 & -7 & -4 & -1 & -2 \\
\hline 5 & BHS. INDONESIA & -14 & -6 & -8 & -4 & -5 & -3 & -4 & -5 & -7 & 0 & -6 \\
\hline 6 & MATEMATIKA & -11 & -8 & -11 & -6 & -7 & -3 & -4 & \begin{tabular}{|l|}
-11 \\
\end{tabular} & -4 & 0 & -8 \\
\hline 7 & SEJARAH & -6 & -9 & -11 & -5 & -7 & -7 & -6 & -7 & -7 & -3 & -3 \\
\hline 8 & BHS. INGGRIS & -10 & -6 & -7 & -6 & -5 & -5 & -5 & -15 & -6 & -1 & -7 \\
\hline 9 & PRAKARYA DAN KWH & 0 & 0 & -3 & -5 & -8 & -8 & 0 & -2 & -2 & -5 & -6 \\
\hline 10 & SENI BUDAYA & -8 & -8 & -14 & -9 & -9 & -8 & 0 & \begin{tabular}{|l|}
-14 \\
\end{tabular} & -8 & -8 & -6 \\
\hline 11 & IPS & 0 & -6 & 0 & 0 & 0 & 0 & 0 & -1 & 0 & -3 & 0 \\
\hline 12 & PENJASKES & -8 & -8 & -8 & -6 & -8 & -4 & -3 & -12 & -7 & -4 & -6 \\
\hline 13 & KKPI & 0 & 0 & -11 & -5 & -8 & -7 & 0 & -8 & -1 & -8 & 0 \\
\hline 14 & FISIKA & -5 & -8 & -8 & -4 & -6 & -4 & -4 & -9 & -1 & -5 & -5 \\
\hline 15 & KIMIA & -5 & -7 & -9 & -2 & -6 & -5 & -6 & -6 & -3 & -5 & -6 \\
\hline 16 & BIOLOGI & -7 & -1 & -6 & -4 & -7 & -5 & -4 & -1 & 0 & -8 & -4 \\
\hline 17 & DASAR KOMPETENSI C1 & 0 & -7 & -2 & -7 & -9 & -3 & -2 & -16 & 0 & -2 & 0 \\
\hline \multirow[t]{3}{*}{18} & PRODUKTIF & -26 & -22 & -70 & -33 & -12 & -10 & -15 & \begin{tabular}{|l|}
-28 \\
\end{tabular} & -9 & -10 & -29 \\
\hline & JUMLAH & -116 & -105 & -187 & -117 & -109 & -81 & -60 & -148 & -60 & -78 & -91 \\
\hline & GRAND TOTAL & \multicolumn{11}{|c|}{-1152} \\
\hline
\end{tabular}

Based on the data in table $4.3 \mathrm{~b}$, the number of shortages of vocational school teachers in Maluku is 1152 people. The number of shortages of teachers in vocational schools in Maluku varies widely between districts. Based on the data in table 4.3b, the number of shortages of vocational school teachers in Maluku is -1152 , with details: Buru district, -116 ; Bursel regency as much as -105 ; central Maluku as much as 187; Southeast Maluku as much as -117; MBD of 109; Tanimbar islands as much as -81 ; Aru islands as much as -60 ; SBB of -148 ; SBT as much as -60 ;
Ambon city as many as 78 and Tual city as many as 91.

\subsubsection{Feasibility Analysis of Principals and Teachers}

The feasibility analysis of school principals and teachers will use 6 parameters, namely S1 / DIV diploma, teaching according to the field of study/expertise, certified, rank/class, with NUPTK (teacher), NUKS (school principal) and working period; the result is as shown in Figure 2.

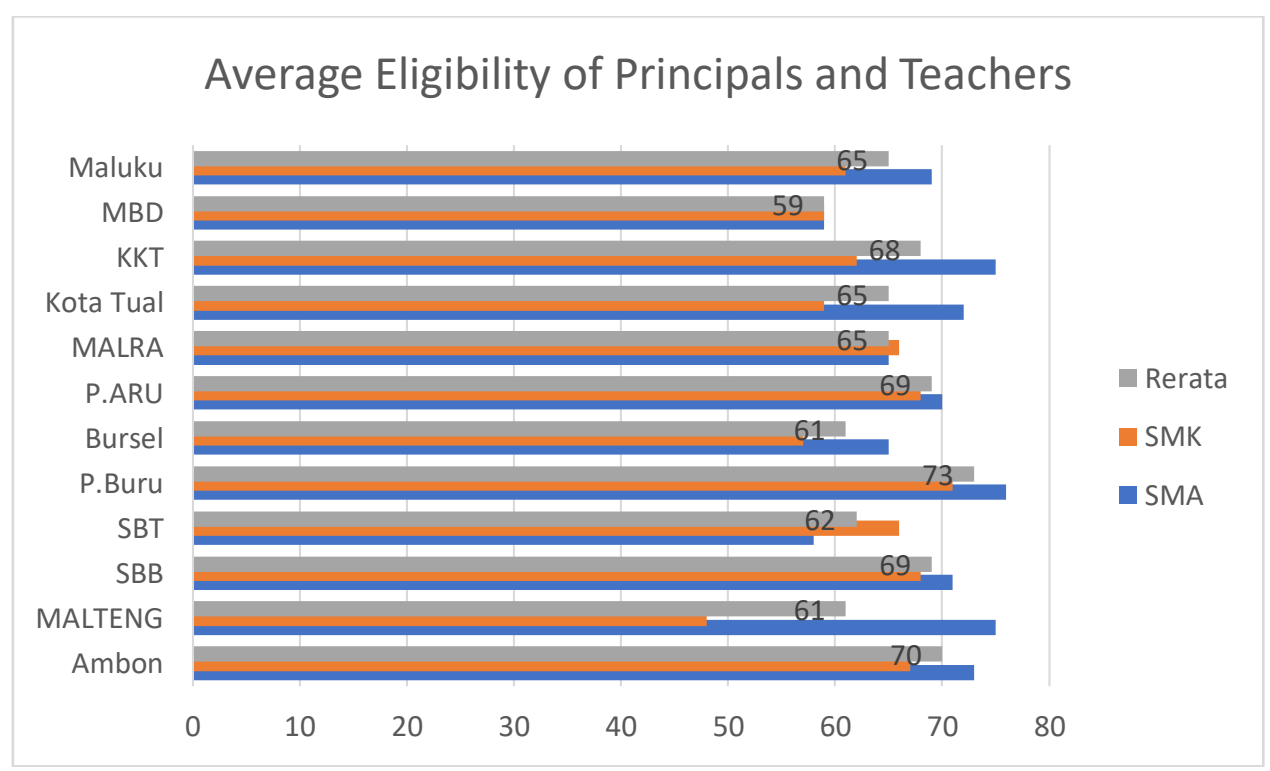

Figure 2. Average Eligibility of Principals and Teachers

Based on graph 4.7, the average eligibility of principals and teachers of High Schools and Vocational Schools in Maluku are in the poor category $(65 \%)$.

\subsection{Discussion}

Based on the results of the analysis of the strengths and weaknesses of teachers, Maluku Province still has a shortage of civil servant teachers in both High and Vocational Schools (see Figure 16.94 and Figure 19.28). 
According to Permendiknas Number 41 of 2007 concerning Process Standards Regarding the Maximum Number of Students in each study group is determined as follows: Primary schools, minimum 20, maximum 28 students/class; Junior High School minimum 20 maximum 32 students/class; Senior High School a minimum of 20 and a maximum of 32 students/class and a Vocational School of at least 15 a maximum of 32 students/class. The results of the calculations provide information that when viewed from the ratio of teachers to students in Maluku Province, based on education units, there is an excess of teachers in Maluku Province. Meanwhile, if it is seen from the ratio of students to teachers based on the subject areas they are teaching, there are still disparities (Mismatch).

The imbalance of the ratio of students to teachers based on the subject areas they provide is due to the strong interference of local elites in the placement and distribution of teachers. Local elites are getting fresh air as the era of regional autonomy was rolled out in 2011. Through the autonomy era, there was a return of central power to the regions. Teachers have been capitalized by local elites to gain majority votes in the elections for Mayor / Regent, Regional Head, and Regional People's Representative Council. The distribution, placement, promotion, and career development of teachers and school principals are highly dependent on teacher affiliation with local elites. Distribution and equality of teachers in this context are not placed on the principles of clean and good governance which prioritize the principles of meritocracy, transparency, competence, and performance are displaced and replaced by bad governance practices that prioritize system spoil. Thus, transactional politics and the principle of the symbiosis of mutualism are heavily practiced by local elites. The local elite disposition determines the position or career of teachers and principals. Teachers who act as success teams, get wind of heaven with promotions while those who have no political affiliation with the ruling elite suddenly get demoted and then transferred as convicts to remote areas.

The shortage of teachers in Maluku is also due to the fact that some teachers who work in Maluku Province choose to return to their places of origin for security reasons. Since 1919-2007 there have been social conflicts in Maluku Province. The social conflict in Maluku has triggered the migration of large numbers of teachers outside the Maluku region. As a result, many teachers who were not Maluku people chose not to return. In addition to the weak regulations governing the placement and distribution of teachers, family reasons provide an opening for migrant teachers to return to their hometowns after attaining civil servant status. The results of this study are in line with the results of the study in China. The survey shows that non-local teachers tend to move to other schools. Non-local teachers are more likely to move to their hometown for family reason. These findings indicate that teacher recruitment with the priority of local sons is a solution to reducing teacher migration and retaining teachers in teacher-short areas, Yunbo Liu, Yi Wei \& Sen Zhou [20].

The unequal distribution of teachers in Indonesia as a result of management is not based on school needs, but rather on teachers' personal needs. Teacher transfers or transfers are generally initiated by individual teachers based on their interests and not those of the school or district. The Education Office is generally passive, either giving permission or not giving permission in responding to a request to move from a teacher. As a result, there is often a surplus of teachers, USAID [21]. The USAID study is confirmed by a study in the United States which found that some teachers do not feel comfortable in school and choose to move because they are not satisfied with working conditions at school. As many as 32 percent of teachers who moved to new schools because they were not satisfied with the conditions of their work. Likewise, a study of former teachers in Illinois. It found that about one in five new teachers (19 percent) with one to five years of work experience were forced to leave school in Illinois. Working conditions are the main reason for teachers not to continue their work, Luekens [22]. Incentive factors and the appropriateness of teacher placement with the competence and atmosphere of the school also triggered teachers to leave their profession or move to another school. Many teachers leave their profession because of poor incentives and dissatisfaction with their work. Dissatisfaction often occurs due to wrong placement. Teacher surveys across the country show that positive perceptions of the school atmosphere correlate with teachers' intentions to remain in school, Hirsch, Emerick, Church, \& Fuller [23] Hirsch [24].

In that context, the right policy is needed. The regular rotation policy, scholarships for prospective teachers from the regions, driving teachers, contract teachers, and mobile teachers should be appreciated. In China, for example, policies to address the shortage of qualified teachers in remote rural areas have issued a Free Teacher Education (FTE) policy, a Special Post Teacher (SPT) policy, and a teacher rotation policy. FTE is carried out by the government in partnership with Teacher Education colleges. The steps taken are recruiting high school graduates who excel and are interested in becoming teachers with guaranteed free education and will immediately work in rural schools for two years after graduation. The SPT also uses alternative recruitment strategies to attract tertiary education graduates to become teachers in poor rural schools ... The teacher rotation policy provides access for teachers and principals from high performing schools to transfer to difficult or low performing schools of varying duration varies from month to year during their careers, An X \& Ding W [25]. 
In this study, the author also analyzed the feasibility level of school principals and teachers using 6 parameters, namely diploma qualification, competency suitability with the field of study being handled, certification, rank/class, ownership of Unique Educator, and Education Personnel Number (NUPTK) for teachers, ownership of Unique Numbers. Principal (NUKS) for school principals and tenure. Overall, the level of feasibility of school principals and teachers in Maluku Province is in the poor category (65\%). In that context, improving the quality of human resources becomes a priority scale so that school principals and teachers play an optimum role in improving the quality of student learning.

\section{CONCLUSIONS}

Equitable distribution of teachers is a prerequisite for the learning process to take place effectively and efficiently. The number of teachers needed in Maluku Province is currently 8,391 ; The number of available as many as 4,804 people and there is still a shortage of 3,587 people with details of $-2,435$ High Schools and Vocational Schools as many as $-1,152$ teachers. Analysis of the ratio of students to teachers, there has been an excess of teachers in all districts. Meanwhile, the analysis of the ratio of students to teachers based on the subject areas being handled still occurs mismatch. The problem of teacher shortages is due to lower regulations as the elaboration of the 5 Ministerial Joint Decree (Surat Keputusan Bersama (SKB)) on the arrangement and distribution of teachers does not yet exist. The politicization of teachers by local elites; social conflict in Maluku; teachers' reluctance to work in disadvantaged areas due to difficulties in access along with inadequate welfare and teacher dissatisfaction due to the unfavorable school atmosphere; weak law enforcement for teachers who are disciplined and the tendency for teachers who are not Maluku people to return to their school or area of origin after obtaining a Letter of Appointment as a Civil Servant.

\section{RECOMMENDATIONS}

A regulation at the regional level is needed as an elaboration of the Ministerial Decree that regulates teacher governance and distribution; Addition of teacher quota through transparent, accountable and measurable selection on a priority scale for placement in disadvantaged areas; Teacher replacement and redistribution according to competence to prevent disparities; Collaboration partnerships with educational institutions for education personnel so that Field Experience Practical students are integrated with the Real Work Lecture program so as to help schools with teacher shortages; Mobile Teacher which enables teacher mobility from superior schools to schools with underperforming regularly; Recruitment of superior seeds from High School graduates with official bond scholarships to study at educational staff educational institutions and ready to be employed in schools that lack teachers after graduating and recruitment of alternative teachers on a priority scale for sons of the soils.

\section{REFERENCES}

[1] Goldhaber, D., Lavery, L., \& Theobald, R. (2015). Uneven playing field? Assessing the teacher quality gap between advantaged and disadvantaged students. Educational researcher, 44(5), 293-307.

[2] L. W. Paine, Making schools modern: Paradoxes of educational reform. In: Andrew G. Walder, editor. Zouping in transition: The process of reform in rural north China. Cambridge, MA: Harvard University Press; 1998. p. 205-35. 17.

[3] L. Han, Is centralized teacher deployment more equitable? Evidence from rural China. China Econ Rev. 2013 Mar; 24:65-76.

[4] L. Karma, Teacher Placement in Schools of Bhutan: An explorativestudy.https://www.researchgate.net/pub lication/322735607Teacher_Placement__ in Schools_of_Bhutan_An_explorative_study.2016. Retrieved, August 1, 2020.

[5] S. Anggara, Kebijakan Publik. Bandung : CV. Pustaka Setia, 2014

[6] Baldwin, R., Forslid, R., Martin, P., Ottaviano, G., \& Robert-Nicoud, F. (2011). Economic geography and public policy. Princeton University Press.

[7] P. Rahabav, Kepemimpinan Kepala Sekolah Di Era Otonomi Daerah. 2014. Yogyakarta: Kanisius.

[8] P. Rahabav, Kebijakan Pendidikan di Era Covid 19. Makalah Seminar. Ambon, 12 Maret 2020.

[9] W. N. Dunn, Penantar Analisis Kebijakan Publik. Edisi Kedua. 2013. Yogyakarta: UGM.

[10] Kemdikbud, (2016). Hasil UKG.https://infomenarik.net/hasil-ukg-kemendikbud-tahun-2015/

[11] N. Agnesty, Kebijakan Pemerataan Guru ( Studi Kasus Pada Dinas Pendidikan Pemuda Dan Olahraga Kabupaten Maluku Tengah). Tesis Magister. 2015. Universitas Pattimura, Ambon.

[12] S. H. Loilatu, Analisis Kebijakan Pemerintah Daerah Dalam Pemenuhan Kebutuhan Guru di Kabuapten Buru Selatan. Tesis, Program Studi Manajemen Pendidikan. 2017. Pascasarjana Universitas Pattimura.

[13] R. Evita, Evaluasi Kebijakan Pemerataan Guru Sekolah Menengah Atas/Sekolah Menengah Kejuruan Pada Dinas Pendidikan dan Kebudayaan 
Kabupaten Maluku Barat Daya. Tesis, Program Studi Manajemen Pendidikan. Pascasarjana Universitas Pattimura, 2017.

[14] Kemdikbud, Analisis Sumber Daya Manusia Pendidikan Dasar dan Menengah Tahun 2015/2016. Jakarta: Kementerian Pendidikan Dan Kebudayaan Pusat Data dan Statistik Pendidikan Dan Kebudayaan. 2016.

[15] Kompas, S. K. (2013). Skor PISA: Posisi Indonesia Nyaris Juru Kunci. Website: kompas.com

[16] D. L. Fixes, S. F. Naoom, K. A. Blasé, R. M. Friedman, Implementation Research: A Synthesis of the Literature. 2005. http://www.popline.org/node/266329

[17] J. A. Durlak, E. P. DuPre, Implementation Matters: A Review of Research on the Influence of Implementation on Program Outcomes and the Factors Affecting Implementation." American Journal of Community Psychology, 2008, pp. 41 (3-4): 327-50.

[18] Hill, M., \& Hupe, P. (2002). Implementing public policy: Governance in theory and in practice. Sage.

[19] I. Kintamani, Analisis Data Pendidikan. disajikan sebagai bahan pelatihan regional. 2007. Pusat Statistik Pendidikan.

[20] L. Yunbo, Y. Wei, S. Zhou, The draw of home: How does teacher's initial job placement relate to teacher mobility in rural China? https://doi.org/10.1371/journal. pone.0227137. 2020. Retrieved Juli 20, 2020.
[21] USAID, Workshor Analisis Kebijakan. Penataan dan Pemerataan Guru. Modul Penataan Dan Pemerataan Guru Workshop Analisis Kebijakan Penataan. 2016. Jakarta: USAID.

[22] M. T. Luekens, D. M. Lyter, E. E. Fox, K. Chandler, Teacher attrition and mobility: Results from the teacher follow-up survey, 2000-01 (NCES 2004-301). Washington, DC: National Center for Education Statistics. 2004. Retrieved February 8, 2010, from http://nces.ed.gov/pubs2004/2004301.pdf.

[23] E. Hirsch, S. Emerick, K. Church, E. Fuller, North Carolina teacher working conditions survey interim report (ERIC Document Reproduction Service No. ED499274). Chapel Hill, NC: Center for Teaching Quality. 2006. Retrieved February 8, 2010 , from http://www.eric.ed.gov/ERICDocs/data/ericdocs $2 \mathrm{~s}$ q1/ content_storage_01/0000019b/80/3a/e5/58.pdf

[24] E. Hirsch, S. Emerick, K. Church, E. Fuller, Teacher working conditions are student learning conditions: A report on the 2006 North Carolina Teacher Working Conditions Survey (ERIC Document Reproduction Service No. ED498770). Hillsborough, NC: Center for Teaching Quality. 2007. Retrieved February 8, 2010, from http://eric.ed.gov/ERICDocs/data/ericdocs2sq1/con tent_storage_01/0000019b/80/34/e7/b9.pdf

[25] D. W. An X, The evaluation of "Special Post Teacher" policy. J Chinese Soc Educ. 2014; (11):1-6. In Chinese. 